\title{
INVESTIGASI KARAKTERISTIK HAMBATAN PENTAMARAN BENTUK LAMBUNG WIGLEY DAN CHINE DENGAN MENGGUNAKAN CFD
}

\author{
Wiwin Sulistyawati ${ }^{1}$ \\ Prodi Teknik Perkapalan, Universitas Pembangunan Nasional “Veteran” Jakarta, Jakarta Selatan, Indonesia ${ }^{1}$ \\ email $^{1}$ : w12n_sby@yahoo.com
}

\begin{abstract}
Several studies of multi-hulls ship showed that hull resistance could be predicted from position between the each hull. The design optimization of the hull form could be considered by minimizing resistance, which is generally the sum of the viscous resistance and the wave making resistance of the ship model. This paper presents an investigation of pentamaran hull form with chine hull form to the effects of outriggers position, asymmetry, and deadrise angles on the resistance characteristics. This research investigated the resistance characteristics by modeling pentamaran hull form using chine with symmetrical main hull and asymmetric outboard on the variation deadrise angles: $25^{\circ}, 30^{\circ}, 35^{\circ}$ and Froude number 0,1 to 0,7 . We examined the calm water resistance characteristics of six pentamaran models with chine-hull form by variation of deadrise angles using Ansys CFD. Increasing the deadrise angle of chine hull form contribute to the resistance due to the interaction of the wave systems produced by each demihull. Strong interaction effect on the resistance coefficient component was found for change in the hull length as well. Compared to the wigley hull form, the maximum drag reduction of the chine hull form was reduced by $18.05 \%$ in deadrise $25^{\circ}, 16.1 \%$ in deadrise $30^{\circ}$, and $18.19 \%$ in deadrise $35^{\circ}$. While the smallest value of total resistance coefficient was generated from chine $35^{\circ}$ at $R / L: 1 / 14$ and $R / L: 1 / 7$. Optimum hull form for minimum resistance has been obtained, so it is interesting to continue with angle of entrance and stem angle of hull for further research.
\end{abstract}

Keywords: pentamaran; deadrise angles; resistance; CFD.

\section{LATAR BELAKANG}

Pada banyak penelitian telah membuktikan bahwa kapal dengan banyak lambung (multi hull) lebih baik dibandingkan dengan kapal mono hull, yaitu: volume ruangan yang luas, dek yang besar, hambatan yang rendah pada kecepatan tinggi, stabilitas yang baik, dan olah gerak (performance seakeeping) yang baik pula. Suatu desain kapal yang optimum adalah mencapai kecepatan yang ditentukan dengan kebutuhan daya yang minimum. Posisi side hull terhadap main hull mempunyai pengaruh terhadap hambatan gesek dan stabilitasnya (Oller, et al. 2003). Hambatan gesek (frictional resistance) pada pentamaran meningkat akibat dari penambahan luas permukaan basah (wetted surface area) dari lambung-lambungnya, akan tetapi hambatan penyebab gelombang (wave making resistance) dapat diturunkan dengan bentuk lambung yang ramping. (Ikeda, et al. 2005) Penurunan hambatan gelombang dan peningkatan hambatan gesek dipengaruhi oleh perbandingan panjang lambung terhadap lebar (L/B).

Bentuk lambung kapal (hull form) adalah hal sangat penting dalam menentukan besarnya hambatan penyebab gelombang (wave making resistance). Penelitian pentamaran pada umumnya menggunakan bentuk lambung Wigley, penelitian ini melakukan investigasi pada bentuk lambung chine dan membandingkan dengan bentuk Wigley. Bentuk lambung chine dari beberapa penelitian menunjukkan keuntungan seperti: dapat menurunkan hambatan, mudah dan cepat dalam proses pembangunan kapal. Dari eksperiment (Chengyi 1994), bentuk chine yang simetris pada kapal katamaran dapat memperkecil hambatan gelombang, dimana interferesensi antar lambung penyebab hambatan akan cenderung turun pada $\mathrm{Fn}>0.5$. (Blount 1995) mendapatkan bahwa model chine lebih menguntungkan pada $\mathrm{Fn}>0.75$ dibandingkan dengan model NPL series (Bailey 1976), sedangkan dari segi performance seakeeping, 
model rounded lebih unggul pada kondisi displacement. Selanjutnya (Blount and McGrath 2009) menunjukkan bahwa bentuk chine mempunyai stabilitas dinamik yang lebih baik pada saat kecepatan tinggi. (Moraes, et al. 2004) dengan menggunakan metode teori Michell dan program komputer 3D Shipflow menganalisis komponen hambatan pada katamaran saat kecepatan tinggi dan perairan dangkal. Bentuk lambung Wigley pada perairan dalam mempunyai nilai Cw (wave coefficient) terbesar pada $0.3<$ $\mathrm{Fr}<0.6$, dan pada perairan dangkal nilai $\mathrm{Cw}$ terbesar pada Fr 0.4. Sedangkan pada bentuk lambung chine, nilai $\mathrm{Cw}$ mengalami penurunan pada $0.6<\mathrm{Fr}<0.7$ sejalan dengan kenaikan kedalaman, nilai $\mathrm{Cw}$ terbesar di perairan dangkal terjadi pada Fr 0.4 .

Performance kapal ditentukan oleh parameter-parameter: $\mathrm{L} / \mathrm{B}, \quad \mathrm{A}_{\mathrm{P}} / \mathrm{V}^{2 / 3}, \mathrm{LCG}$, deadrise angle, variasi sudut sepanjang badan kapal, dan shape dari chine (Begovic and Bertorello 2012). Penggunaan bentuk chine pada multi hull dilakukan oleh (Bari and Matveev 2016) yang mendapatkan gaya hidrodinamik katamaran lambung chine pada deadrise angle $0^{\circ}-20^{\circ}$ koefisien gaya angkat meningkat sejalan dengan makin besarnya deadrise angle dan Fn, serta makin pendek jarak outriggers. Akan tetapi pada deadrise angle terbesar $\left(20^{\circ}\right)$ dan Fn semakin besar serta jarak outriggers makin jauh maka terjadi efek yang komplek dimana aliran gelombang kearah belakang mengakibatkan tekanan di area belakang kapal, dan juga berakibat pada koefisien gaya angkat. Pada penelitian ini melakukan analisis berdasarkan konfigurasi outrigger (Yanuar, 2015) dengan model chine pada variasi deadrise angle $25^{\circ}, 30^{\circ}$ dan $35^{\circ}$.

\section{HAMBATAN KAPAL}

Eksperimental dan model numerik sangat penting untuk mendapatkan bentuk lambung dengan hidrodinamik dan performans yang baik,serta faktor aman yang tercapai. Eksperimental untuk kapal multi hull dilakukan pertama kali oleh (Hsiung and $\mathrm{Xu}$ 1988) pada kapal katamaran untuk mendapatkan hull yang optimal dengan hambatan yang minimum. Selanjutnya (Wilson, et al. 1993) melakukan analisis dan eksperimen dengan towing untuk Wave Cancellation Multihull (WCM) pada Trimaran. (Suzuki and Ikehata 1993) serta (Andrews 1995) melakukan optimisasi konfigurasi pada Trimaran. Dan (Tuck and Lazauskas 1998) dengan menggunakan thin ship teori menentukan konfigurasi jarak optimum multihull untuk mendapatkan hambatan gelombang yang minimum. (Peng 2001) melakukan pendekatan formulasi numerik secara komputasi dengan metode teori Michell menentukan hambatan dan olah gerak kapal pada katamaran, trimaran, quadrimaran (tetramaran) dan Pentamaran dengan menggunakan model Wigley pada beberapa variasi konfigurasi. Peng menyatakan bahwa pada multi hull hambatan gelombang selalu menjadi komponen penghambat pada saat kecepatan meningkat atau nilai Fn semakin besar.

Dasar dari hipotesis Froude menyatakan bahwa hambatan total terdiri dari 2 komponen, yaitu: hambatan gesek (frictional resistance, $R_{f}$ ) dan hambatan sisa (residuary resistance, $\mathrm{R}_{\mathrm{r}}$ )

$$
R_{t}=R_{f}+R_{r}
$$

Analisis data eksperimen menggunakan metodologi ITTC'57 untuk menghitung koefisien hambatan total $\left(\mathrm{C}_{\mathrm{t}}\right)$ :

$$
\begin{aligned}
C_{t} & =C_{f}+C_{r} \\
C_{f} & =\frac{0.075}{(\log R n-2)^{2}}
\end{aligned}
$$

Pentamaran terdiri dari satu lambung utama, dua lambung dalam dan dua lambung terluar yang mempunyai perbedaan Reynold number, maka koefisien hambatan gesek dapat dihitung dengan rumus:

$$
\begin{aligned}
& C_{f}=C_{f m a i n} \frac{S_{\text {main }}}{S_{T}}+C_{f 1} \frac{2 \text { side }_{1}}{S_{T}}+ \\
& C_{f 2} \frac{2 \text { Side }_{2}}{S_{T}}
\end{aligned}
$$

maka koefisien hambatan sisa (residuary resistance, $\mathrm{R}_{\mathrm{r}}$ ):

$$
C r=C t-C f
$$

Data ekperimental dari penelitian Yanuar (2015) digunakan untuk validasi dari analisis CFD pentamaran bentuk lambung Wigley dengan sisi lambung dalam asimetri. Eksperimen dilakukan pada 9 konfigurasi pada variasi Fr 0.1 - 0.7. Pada model IIA (Gambar 1) konfigurasi S/L (separation/ length of main hull) 3/16 dan $\mathrm{R} / \mathrm{L}$ (stagger/ length of main hull) 1/ 20 pada Fr 0.35 hambaran mengalami penurunan sebesar $25 \%$. 


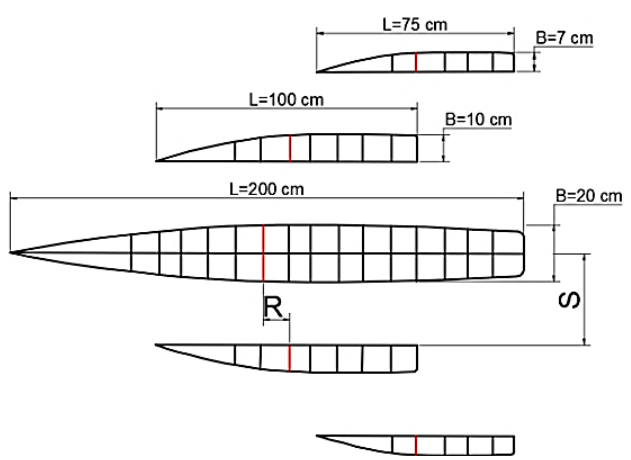

Gambar 1. Configuration model Ila (Yanuar, 2015)

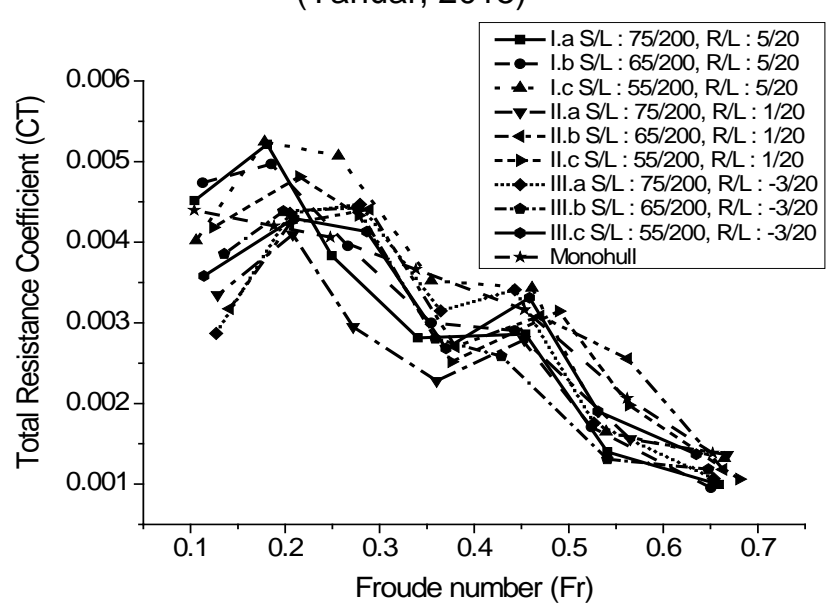

Gambar 2. Koefisien hambatan total pada konfigurasi pentamaran bentuk Wigley (Yanuar, 2015)

Pada Fr 0.2 to 0.7 koefisien hambatan mengalami tren penurunan seperti yang ditunjukkan pada Gambar 2.

Penelitian ini mengimplementasikan simulasi numerik dengan menggunakan CFD pada model eksperimen Yanuar (2015). Hasil dari konfigurasi IIA (model Wigley) dijadikan sebagai analisis model awal yang kemudian membandingkan dengan model chine pada variasi sudut deadrise: 25o, 30o, 35o.

Langkah awal adalah pemodelan pentamaran dengan menggunakan linesplan dari model eksperimen Yanuar (2015). Kemudian dilakukan modifikasi model Wigley dengan model chine pada posisi S/L yang sama/ tetap. Spesifikasi dari bentuk lambung Wigley dan chine ditunjukkan pada Tabel 1. Sedangkan midship section bentuk lambung Wigley and chine ditunjukkan pada Gambar 3 dan 4.

Perubahan bentuk lambung dari Wigley ke chine menyebabkan perubahan L/B: 12; 13.75; 16.5 pada nilai konstan B/T: 2.9 dan H/T: 2.1, sehingga dari perubahan tersebut terdapat 6 konfigurasi baru. Dari masing-masing sudut deadrise terdapat 2 konfigurasi seperti yang ditunjukkan pada Gambar 5. Masing-masing konfigurasi pada tiap-tiap lambung chine adalah perubahan posisi inner dan outer sisi lambung.

\section{Teknik Meshing}

Blazek (2001) dan Ferziger (2002) menyatakan bahwa kualitas mesh sangat penting untuk menampilkan hasil CFD. Jumlah total elemen dari mesh harus cukup besar untuk mempresentasikan geometri dan fenomena aliran dari domain. Spesifiasi domain pada permukaan bebas model untuk boundary secara detail ditampilkan pada Tabel 2. Pada penelitian ini untuk meshing telah dilakukan sebanyak 5 kali dengan jumlah elemen: 4.5 juta, 7 juta, 9 juta, 10 juta dan 11 juta sebagai evaluasi konvergensi. Untuk konvergensi dan keyakinan terhadap ketidakpastian numerik maka proses meshing untuk ukuran elemen dari boundary adalah $0, .1$, sedangkan untuk model (lambung) ukuran elemen diatur dari 0.005 hingga 0.003 . Hasil poses meshing pada model ditunjukkan pada Gambar 6, dihasilkan sekitar 10 juta elemen. Metode meshing dengan menggunakan ICEM menghasilkan mesh secara otomatis. Mesh yang dihasilkan dari ICEM menggunakan transisi lambat untuk memperbaiki mesh yang dibuat. Elemen Unstructured tetrahedral dipilih dalam proses meshing untuk domain dan model (lambung).

Jumlah total elemen, ukuran mesh sama dengan penentuan nilai $\mathrm{Y}^{+}$pada beberapa variasi mesh. $\mathrm{Y}^{+}$adalah suatu non-dimensional jarak dari dinding (wall) ke grid poin pertama yang sama dengan angka Reynolds, yang dinyatakan pada persamaan 6. Hal ini untuk menggambarkan pengaruh aliran pada dinding apakah laminar atau turbulen.

$$
y^{+}=\frac{U_{\tau} y}{v}
$$

\section{Dimana $U_{\tau}$; kecepatan gesek sebagai} perbandingan antara shear stress pada wall $\left(\tau_{\mathrm{w}}\right)$ dan kerapatan $(\rho)$, y; jarak dari permukaan dinding, $v$; viskositas kinematik.

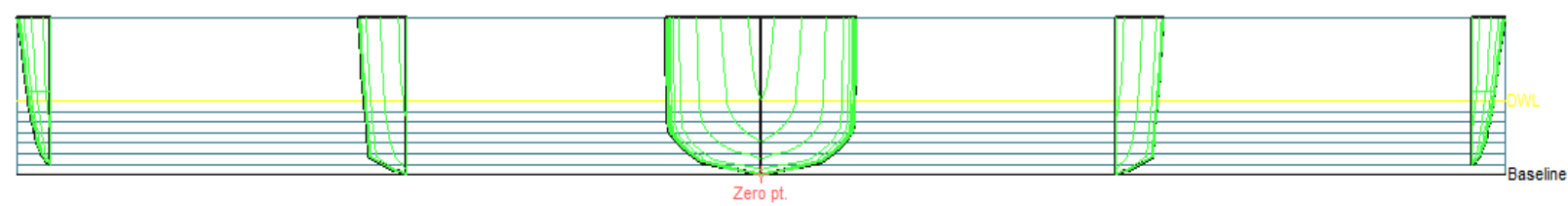

Gambar 3. Pentamaran bentuk Wigley 


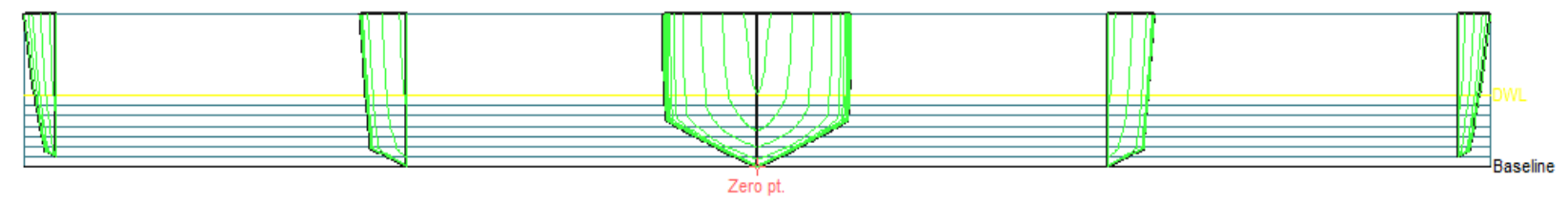

Gambar 4. Pentamaran bentuk chine

Tabel 1. Spesifikasi lambung Wigley dan Chine

\begin{tabular}{|c|c|c|c|c|c|c|}
\hline \multirow{2}{*}{$\begin{array}{c}\text { Main } \\
\text { Dimension }\end{array}$} & \multicolumn{3}{|c|}{ Wigley } & \multicolumn{3}{|c|}{ Chine $25^{\circ}$} \\
\hline & Main & Inner side & Outer side & Main & Inner side & Outer side \\
\hline LOA & $2.00 \mathrm{~m}$ & $1.00 \mathrm{~m}$ & $0.75 \mathrm{~m}$ & $2.40 \mathrm{~m}$ & $1.02 \mathrm{~m}$ & $0.93 \mathrm{~m}$ \\
\hline B & $0.20 \mathrm{~m}$ & $0.10 \mathrm{~m}$ & $0.07 \mathrm{~m}$ & $0.20 \mathrm{~m}$ & $0.10 \mathrm{~m}$ & $0.07 \mathrm{~m}$ \\
\hline$T$ & $0.07 \mathrm{~m}$ & $0.07 \mathrm{~m}$ & $0.06 \mathrm{~m}$ & $0.07 \mathrm{~m}$ & $0.07 \mathrm{~m}$ & $0.06 \mathrm{~m}$ \\
\hline $\mathbf{H}$ & $0.15 \mathrm{~m}$ & $0.15 \mathrm{~m}$ & $0.14 \mathrm{~m}$ & $0.15 \mathrm{~m}$ & $0.15 \mathrm{~m}$ & $0.14 \mathrm{~m}$ \\
\hline $\mathrm{Cb}$ & 0.57 & 0.59 & 0.58 & 0.59 & 0.67 & 0.55 \\
\hline WSA & $0.39 \mathrm{~m}^{2}$ & $0.18 \mathrm{~m}^{2}$ & $0.11 \mathrm{~m}^{2}$ & $0.55 \mathrm{~m}^{2}$ & $0.30 \mathrm{~m}^{2}$ & $0.21 \mathrm{~m}^{2}$ \\
\hline$\square$ tot & & $24.5 \mathrm{~kg}$ & & & $\approx 24.5 \mathrm{~kg}$ & \\
\hline Main & \multicolumn{3}{|c|}{ Chine $30^{\circ}$} & \multicolumn{3}{|c|}{ Chine $35^{\circ}$} \\
\hline Dimension & Main & Inner side & Outer side & Main & Inner side & Outer side \\
\hline LOA & 2.75 & $1.08 \mathrm{~m}$ & $0.93 \mathrm{~m}$ & $3.30 \mathrm{~m}$ & $1.12 \mathrm{~m}$ & $0.93 \mathrm{~m}$ \\
\hline B & $0.20 \mathrm{~m}$ & $0.10 \mathrm{~m}$ & $0.07 \mathrm{~m}$ & $0.20 \mathrm{~m}$ & $0.10 \mathrm{~m}$ & $0.07 \mathrm{~m}$ \\
\hline $\mathbf{T}$ & $0.07 \mathrm{~m}$ & $0.07 \mathrm{~m}$ & $0.06 \mathrm{~m}$ & $0.07 \mathrm{~m}$ & $0.07 \mathrm{~m}$ & $0.06 \mathrm{~m}$ \\
\hline $\mathbf{H}$ & $0.15 \mathrm{~m}$ & $0.15 \mathrm{~m}$ & $0.4 \mathrm{~m}$ & $0.15 \mathrm{~m}$ & $0,15 \mathrm{~m}$ & $0.14 \mathrm{~m}$ \\
\hline $\mathrm{Cb}$ & 0.52 & 0.65 & 0.55 & 0.44 & 0.62 & 0.55 \\
\hline WSA & $0.61 \mathrm{~m}^{2}$ & $0.31 \mathrm{~m}^{2}$ & $0.21 \mathrm{~m}^{2}$ & $0.69 \mathrm{~m}^{2}$ & $0.32 \mathrm{~m}^{2}$ & $0.21 \mathrm{~m}^{2}$ \\
\hline$\square$ tot & & $\approx 24.5 \mathrm{~kg}$ & & & $\approx 24.5 \mathrm{~kg}$ & \\
\hline
\end{tabular}

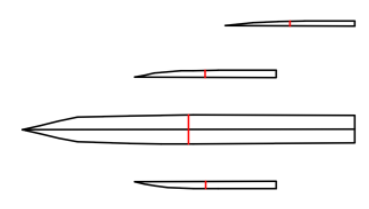

$25 \mathrm{deg}, \mathrm{S} / \mathrm{L}: 3 / 16, \mathrm{R} / \mathrm{L}: 1 / 16$

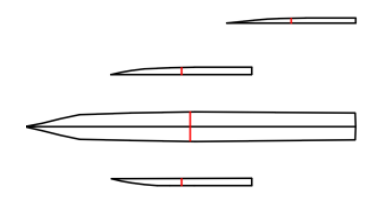

$25 \mathrm{deg}, \mathrm{S} / \mathrm{L}: 3 / 16, \mathrm{R} / \mathrm{L}: 1 / 33$

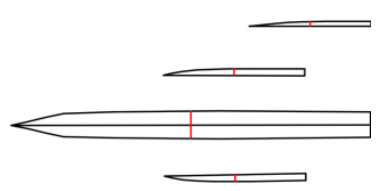

$30 \mathrm{deg}, \mathrm{S} / \mathrm{L}: 3 / 16, \mathrm{R} / \mathrm{L}: 1 / 8)$

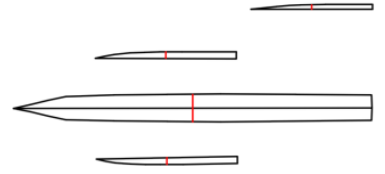

$30 \mathrm{deg}, \mathrm{S} / \mathrm{L}: 3 / 16, \mathrm{R} / \mathrm{L}: 1 / 14$

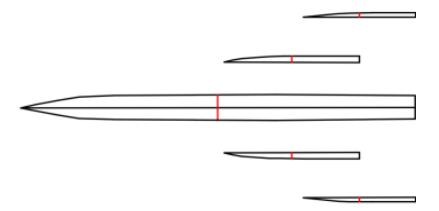

$35 \mathrm{deg}, \mathrm{S} / \mathrm{L}: 3 / 16, \mathrm{R} / \mathrm{L}: 1 / 5$

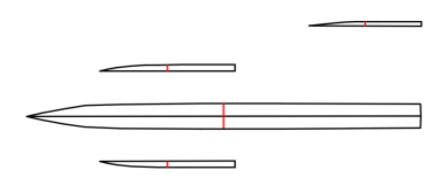

$35 \mathrm{deg}, \mathrm{S} / \mathrm{L}: 3 / 16, \mathrm{R} / \mathrm{L}: 1 / 7$

Gambar 5. Enam konfigurasi baru dari bentuk lambung chine 
Mesh awal yang dihasilkan sebanyak 7 juta elemen yang kemudian ditingkatkan menjadi 10 juta dengan nilai $\mathrm{Y}^{+}$pada lambung $>55$. Pada aliran multi fase, volume fraction ditentukan untuk menghindari residual yang besar, Pengulangan konvergensi diasumsikan sebagai langkah untuk mendapatkan nilai residual yang normal. Untuk residual RMS ditentukan pada nilai 1E-04. Perhitungan pada kondisi steady biasanya terjadi antara 50-100 kali hingga mendapatkan kondisi yang konvergen.Secara keseluruhan proses waktu (time step) yang terlalu lama maka akan menimbulkan konvergensi yang tidak stabil, akan tetapi bila terlalu singkat maka untuk mendapatkan kondisi yang konvergen akan sangat lama

\section{Hasil Analisis}

Analisis pada pentamaran model Wigley dan konfigurasi 6 model chine dengan perbedaan Lpp maka menimbulkan perubahan ukuran dari domain, khususnya pada daerah depan dan belakang kapal yang menyesuaikan dengan panjang kapal. Sebagai tambahan untuk ukuran domain, seting dari mesh dan setup CFD mengikuti pengaturan antara lain: ukuran mesh, kondisi boundary, time step dan kontrol konvergensi.

Dari hasil analisis CFD dan perbandingan dengan data eksperimen ditunjukkan pada Gambar 6 , dimana kedua grafik koefisien hambatan total (Ct) menampilkan tren yang sama.

Perbedaan hasil antara eksperimental dan CFD menggunaka persamaan (7). Rata-rata hasil perbedaan antara eksperimental dan CFD sebesar $3.6 \%$, suatu hasil yang menunjukkan keakuratan setup CFD

$$
\Delta C_{T}=\frac{C_{T \cdot \exp }-C_{T . C F D}}{C_{T \cdot \exp }} \times 100 \%
$$

Tabel 2. CFD simulation properties

\begin{tabular}{|c|c|}
\hline Property & $\begin{array}{l}\text { Fine Mesh } \\
\end{array}$ \\
\hline Type of mesh & Structured (tetrahedral, mixer) \\
\hline Domain Physics & $\begin{array}{l}\text { Homogeneous } \\
\text { multiphase, } K-\varepsilon \text {, automatic wall } \\
\text { function, buoyancy model - } \\
\text { density difference, standard free } \\
\text { surface model }\end{array}$ \\
\hline \multicolumn{2}{|l|}{ Boundary physics: } \\
\hline Inlet & $\begin{array}{l}\text { Inlet, volume fraction, turbulence } \\
\text { intensity } 0.05\end{array}$ \\
\hline Outlet & Outlet, relative pressure \\
\hline side wall & Wall, free slip condition \\
\hline Top & Opening, relative pressure $0 \mathrm{~Pa}$ \\
\hline Hull/ Bottom & Wall, no slip condition \\
\hline Symmetry plane & Along centerline of the hull \\
\hline \multicolumn{2}{|l|}{ Solver settings: } \\
\hline Convergence criteria & $\begin{array}{l}\text { Residuary type: RMS, Target: 10- } \\
\text { e4 }\end{array}$ \\
\hline Multiphase control & Volume fraction coupling \\
\hline
\end{tabular}


Grafik Ct pada bentuk lambung Wigley menunjukkan fenomena puncak dan lembah, dimana bentuk lambung chine tidak terdapat perubahan yang signofikan kenaikan maupun penurunan nilai $\mathrm{Ct}$ pada variasi Fr. Prosentase penurunan hambatan dari bentuk lambung Wigey ke chine dinyatakan dengan persamaan (8).

Grafik prosentase penurunan hambatan dari 6 bentuk lambung chine dintujukkan pada Gambar 11. Untuk nilai maksimum penurunan hambatan dari bentuk Wigley ke chine ditampilkan pada table 3 di bawah ini.

$$
D R(\%)=\left|\frac{C t_{\text {wigley }}-C t_{\text {chine }}}{C t_{\text {wigley }}}\right|
$$

Tabel 3. Maksimum penurunan hambatan

\begin{tabular}{|c|c|}
\hline chine & DR (\%) \\
\hline 25deg R/L 1/16 & 18.05 \\
\hline 25deg R/L 1/33 & 17.80 \\
\hline 30deg R/L 1/8 & 16.10 \\
\hline 30deg R/L 1/5 & 14.76 \\
\hline 35deg R/L 1/14 & 18.02 \\
\hline 35deg R/L 1/7 & 18.19 \\
\hline
\end{tabular}

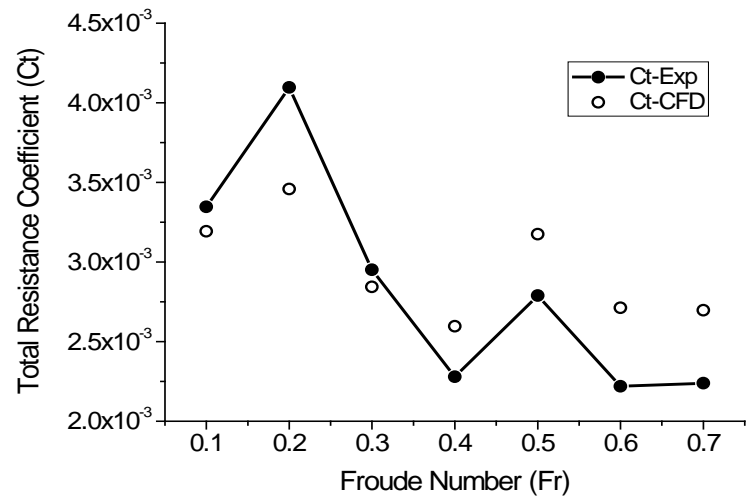

Gambar 7. Perbandingan hasil Ct antara eksperimen dan CFD dari lambung Wigley

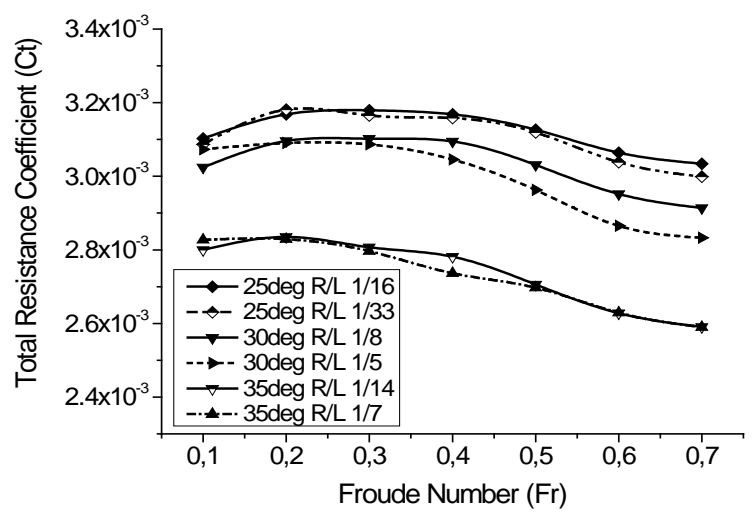

Gambar 8. Hasil koefisien hambatan total (Ct)

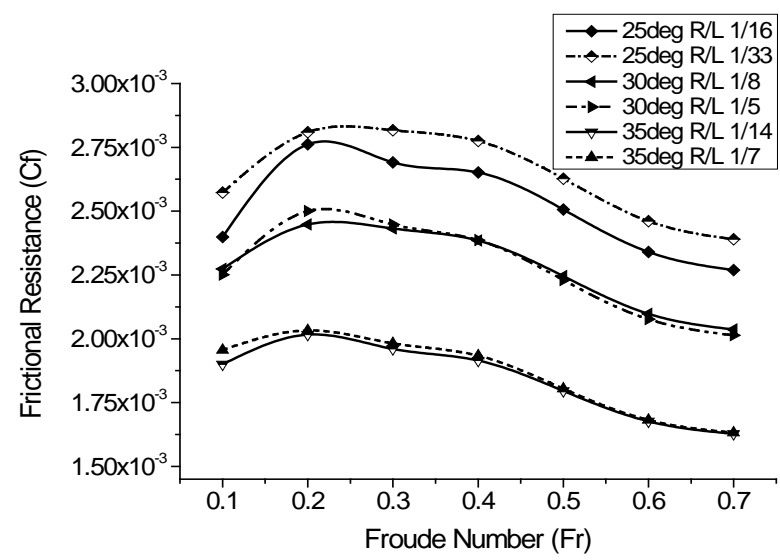

Gambar 9. Hasil koefisien hambatan gesek (Cf)

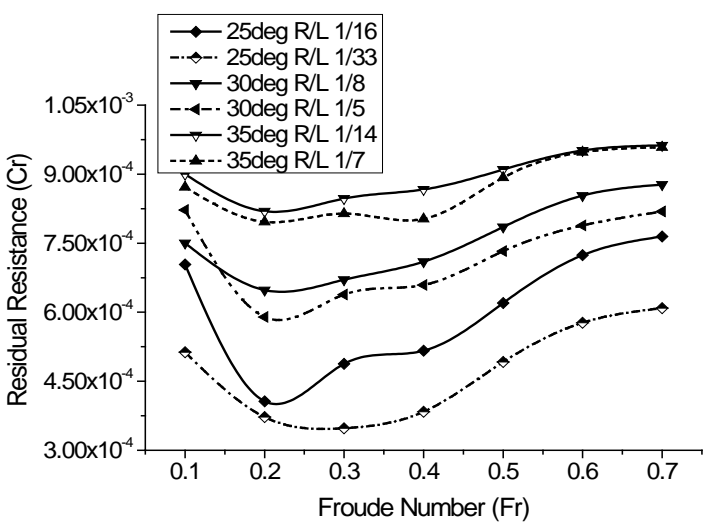

Gambar 10. Hasil koefisien hambatan sisa (Cr)

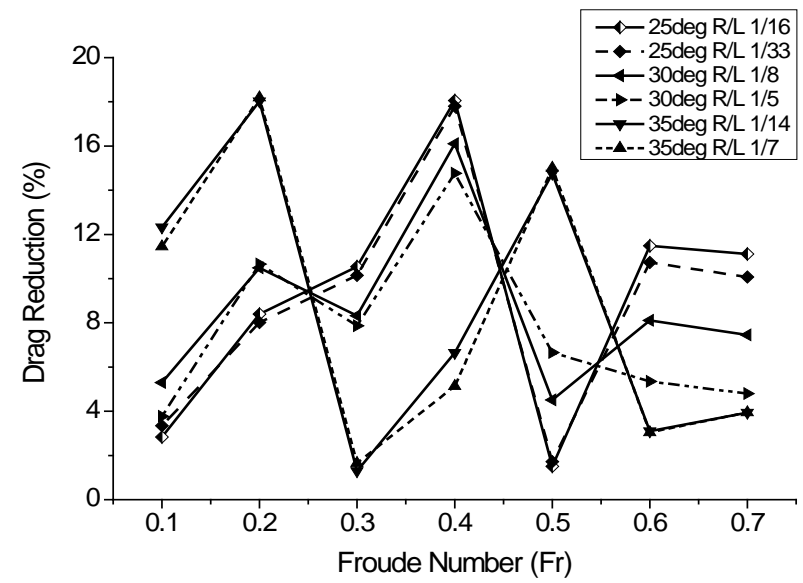

Gambar 11. Persentase penurunan hambatan

Kontur gelombang volume fraction dari simulasi CFD pada Fr 0.7 untuk model lambung Wigley dan chine ditunjukkan pada Gambar 12 dan Gambar 13. Terdapat perbedaan kontur dari gelombang pada model lambung Wigley dan masing-masing chine, dimana warna biru muda menunjukkan gelombang yang besar dibandingkan dengan warna biru tua. Hal tersebut mengidentifikasikan bahwa model lambung Wigley menghasilkan gelombang yang lebih besar dibandingkan dengan model lambung chine. 


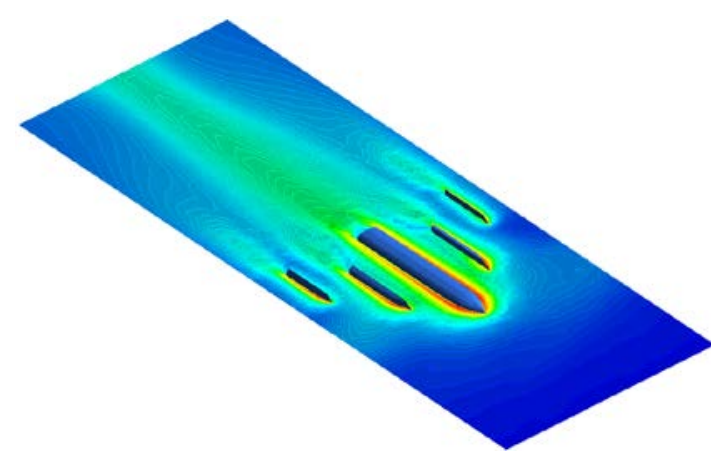

kontur aliran Wigley pada z/Lpp $=0.035$, Fn $=0.7$

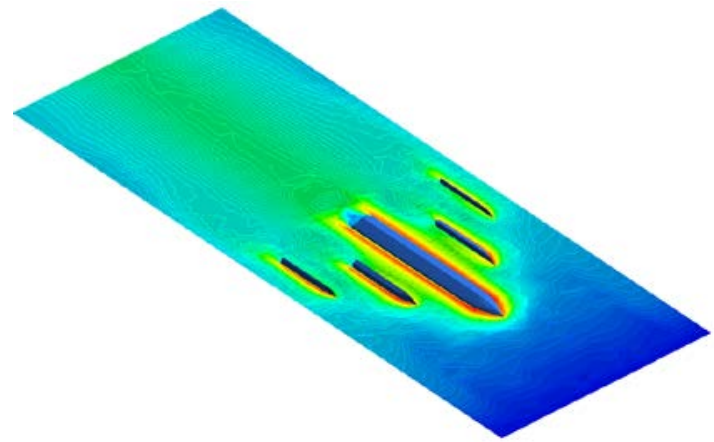

kontur aliran chine $25^{\circ}$ pada $\mathrm{z} / \mathrm{Lpp}=0.03, \mathrm{Fn}=0.7$

Gambar 12. Aliran permukaan bebas, z/Lpp, dari wave pattern

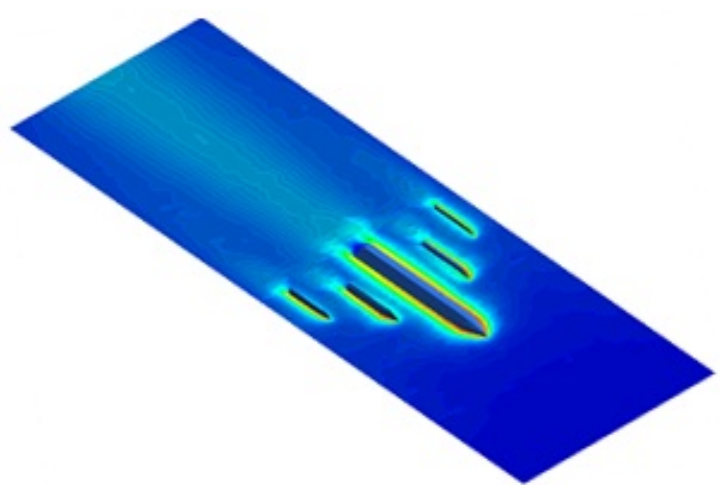

kontur aliran chine $30^{\circ}$ pada z/Lpp $=0.025, \mathrm{Fn}=0.7$

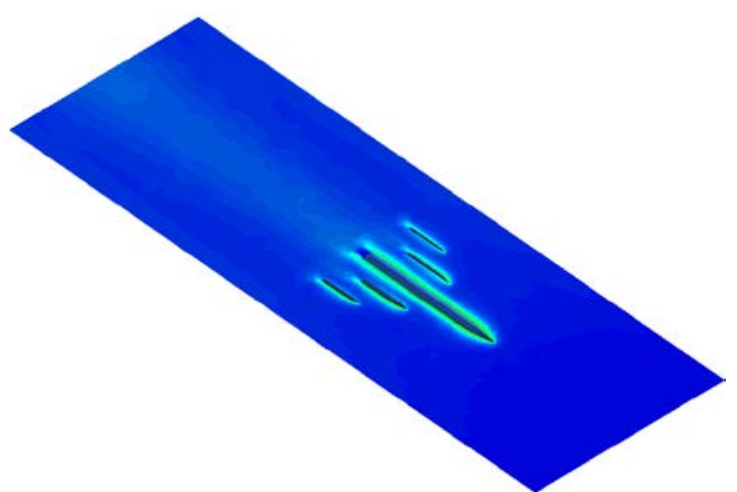

kontur aliran chine $35^{0}$ pada z/Lpp $=0.02, \mathrm{Fn}=0.7$

Gambar 13. Aliran permukaan bebas, z/Lpp, dari wave pattern

\section{Kesimpulan}

Perbandingan analisis CFD pada model lambung Wigley dan chine dengan inner dan outer asimetri menunjukkan kenaikan sudut deadrise berpengaruh terhadap penurunan hambatan. Penurunan hambatan terbesar terjadi pada sudut deadrise $35^{\circ}$ hal ini akibat sudut yang besar sehingga efek gelombang yang terjadi antara lambung-lambung akan saling menghilangkan. Beberapa keuntungan dari bentuk lambung chine dibandingkan dengan Wigley adalah:

- Nilai Ct mempunyai kecenderungan kecil pada L/B yang besar dengan B/T dan $\mathrm{H} / \mathrm{T}$ yang tetap;

- Peningkatan nilai Ct tidak terlalu fluktuatif terhadap kenaikan Fr;

- Sudut deadrise terbesar semakin menurutkan nilai $\mathrm{Ct}$

- Penurunan hambatan terbesar $18.19 \%$ terjadi pada sudut deadrise $35^{\circ} \mathrm{Fr} 0.2$;

Penelitian berkelanjutan yang akan dilakukan adalah investigasi karakteristik hambatan pengaruh sudut masuk air dan sudut stem dari lambung.

\section{DAFTAR PUSTAKA}

Bari, Ghazi S, and Konstantin I Matveev, (2016), Hydrodynamic modeling of planing catamarans with symmetric hulls. Ocean Engineering 115:60-66.

Begovic, E, and C Bertorello, (2012), Resistance assessment of warped hull form. Ocean Engineering 56:28-42.

Blazek J. 2001. Computational Fluid Dynamics: Principles and Applications. Elsevier Science Ltd, Oxford England.

Blount, Donald L, (1995), Factors Influencing the Selection of a Hard Chine or Round-Bilge Hull for High Froude Numbers

Chengyi, Wang, (1994), Resistance charicteristic of high-speed catamaran and its application. Shipbuilding of China 3:003

Hsiung. C.C. and Xu. H, (1988), Determining Optimal Forms of a Catamaran for Minimum Resistance by the Mat hematical Programming Met hodo'. Schiffstechnik Bd.35.

Ikeda, Yoshiho, Emiko Nakabayashi, and Ai Ito, (2005), Concept design of a pentamaran type fast RoRo ship. Journal of the Japan Society of Naval Architects and Ocean Engineers 1:35-42.

Michell, J.H., (1898), The Wave-Resistance of a Ship, Philosophical Magazine, Series 5.Vol. 45, Xo. 272, London, January, pp. 105-1 23.

Moraes, HB, JM Vasconcellos, and RG Latorre, (2004), Wave resistance for high-speed catamarans. Ocean Engineering 31(17):22532282. 
Oller, Erik, Vasilios Nikou, and Konstantinos Psallidas, (2003), Focused Mission High Speed Combatant. DTIC Document.

Peng, Hongxuan, (2001), Numerical computation of multi-hull ship resistance and motion, Dalhousie University Halifax.

Recommended Procedure and Guidelines, (2002), Testing and Extrapolation Methods in Resistance Towing Tank Tests, ITTC 7.5-0202-02.

Yanuar, Gunawan, Kurniawan T. Waskito, and A. Jamaluddin, 2015. Experimental Study Resistances of Asymmetrical Pentamaran Model with Separation and Staggered Hull Variation of Inner Side-Hulls, International Journal of Fluid Mechanics Research, Vol. 42, No. 1. 